\title{
An Evaluation Of The Treatment Methods Of Denture Granuloma: A 5-Year Longitudinal Study.
}

Nadira A Hatim

BDS, MSc (Assis Prof)

\author{
Department of Prosthetic Dentistry \\ College of Dentistry, University of Mosul
}

\begin{abstract}
Aims: To evaluate the prevalence of the position of denture granuloma in the oral cavity, to evaluate the treatment methods of denture granuloma by different conservative prosthetic treatment or by surgical treatment, and to find if there is any relation between the length of the lesion and treatment methods. Materials and methods: Seven hundred and six (706) complete denture patients, age range between (40-70) year were treated by construction of complete maxillary and mandibular dentures, 550 of them attended for adjustment after placement of the prosthesis. Patients are recalled for post insertion care for 5 years. One hundred and seventy two (175) of the (550) patients were presented with denture granuloma. In this study four treatment methods were applied according to the mean length of the lesion by using soft-liner and tissue conditioning materials. Results: Showed that $47.73 \%$ of denture granuloma was located at the vestibule in the canine and premolar mandibular region. There was a relation with sequence of treatment with high significance of $\mathbf{X}^{2}$ analysis. Conclusions: Tissue recovery plays role in treatment of different an important length of denture granuloma.

Key words: Granuloma, Soft liner, Completely edentulous.
\end{abstract}

Hatim NA. An Evaluation Of The Treatment Methods Of Denture Granuloma: A 5-Year Longitudinal Study.. Al-Rafidain Dent J. 2008; 8(2): 246-254.

Accepted for Publication: 7 /5/2008

\section{INTRODUCTION}

Complete dentures are foreign objects in the oral cavity that are accepted and tolerated by the tissue to a degree that is surprising. An oral prosthesis has the potential of producing irritation and inflammation such as denture granuloma of the underlying mucosa ${ }^{(1,2)}$.

Hyperplastic tissue: is an excessive tissue proliferation, usually as a response to chronic irritation ${ }^{(3)}$. This term has been described under the titles of alveolar fibrosis, gingival hyperplasia, epulis fisurat$u^{(4)}$, and denture granuloma ${ }^{(5)}$.

" The denture granuloma is a similar lesion to the fibro-epithelial polyp, modified by the morphology of the tissues and by the nature of the irritant"(6). Hyperplastic soft tissue is often found in the edentulous mouth near the periphery of dentures or under their fitting surface ${ }^{(7-9)}$. It is important that these abnormalities be diagnosed and treated before new denture construction, if needed when correction or adjustment of previous denture can not be obtained $^{(10,11)}$

The aims of this study are: Evaluating the prevalence of the position of denture granuloma in the oral cavity. To evaluate the treatment methods of denture granuloma by different conservative prosthetic treatment or by surgical treatment. And to find if there is any relation between the length of the lesion and treatment methods.

\section{MATERIALS AND METHODS}

Some conditions of soft tissues related to complete dentures encountered during a period of five years between 1995 and 2000 at the university of Mosul, College of dentistry clinics, and discussed from the stand point of the clinical prosthodontic. During this time over of seven hundred and six denture patients, age range between $40-70$ years were treated by construction of complete maxillary, and mandibular dentures in a conventional method. Five hundred and fifty denture patients attended for adjustment after placement of the prosthesis for post insertion care six months periodically. One hundred and seventy two of five hundred and fifty patients were presented with denture granuloma after two years of denture use (Figure 1). 

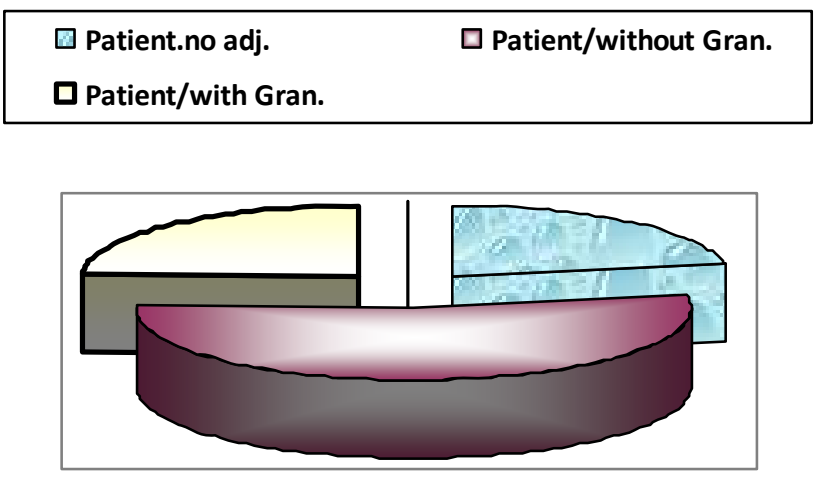

Figure (1): Number of Patients attended to prosthodontic clinic for 5 years.

Patients had the following criteria:

1.All patients had only one set maxillary and mandibular dentures of acrylic resin denture base.

2. No medical history.

3. No history of allergy to dental materials.

4. All patient were wearing successful dentures.

The patients documented the following preliminary form of questionnaire (N0. 1-4), while the author documented the question No.5.

Denture patient questionnaire:

1.Name. Sex Age

Year Phone No.

2.Length of time patient had worn a denture.

3. How many hours the dentures were kept out of patient mouth daily?

4. Fitness of denture. Good..........,or Poor

5. Errors in dentures.

A. Oral hygiene: Good......., Poor ........

B. Vertical dimension of occlusion: Decreased........,Increased........,or Normal

C. Flange extension: Under extended Over extended or Normal

D. Occlusal errors: Yes , No

All the patients were examined in order to study the characteristics of the lesion, and to treat them. After taking medical, and dental histories from the patients, intra oral examination was done by using mouth mirror to localize the lesion.

As impression was taken for the lesion with impression plaster material using spaced special tray constructed for each patient, and poured with Whip mix stone (Louisville, USA, Silky rock Die stone high strength.) according to manu-facturer instructions to measure the lesion by flexible ruler, and digital caliber gauge (Accuracy $0.01 \mathrm{~mm}$.).

Pilot study: Thirty patients with presence of denture granuloma in the vestibule of the mandibular arch at the canine region were selected. The patients were divide randomly into three groups, and treated by the following steps ${ }^{(12,13)}$ (After each two weeks, impression was taken, and measurements of the lesion were done.

First group:

1.Instructing the patient for good oral hygiene.

2.Instructing the patient to remove the prosthesis for 1-4 weeks.

3. Correcting the errors of complete dentures by trimming to make clearance for the hyperplastic tissues without prejudice to retention and stability of the dentures.

4. Instructing the patient to wear the denture at day only. The patient was examined at two weeks interval for three months.

Second group:

The steps of treatment of the first group were done fore this group in addition to the following: The denture was lined with tissue conditioning material (OMF DENT). The material was changed each seven days according to manufacture instructions for eight weeks.

Third group: The steps of treatment of the first group were done fore this group in addition to the following: The offending flange was modified, or relieved at the site of the lesion followed by lining the denture with self curing COE-SOFT material. The material was changed each 14 days according to the manufacture instructions for eight weeks. 
The results of the pilot study showed the followings:

1.The lesion disappeared in all patients with length measurements of lesion range between $(1-4 \pm 1 \mathrm{~mm}$.) during a period range (6-8 weeks) after relief only.

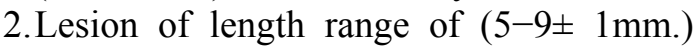
disappeared after tissue conditioner application during aperiod range $6-8$ weeks.

3.Lesion of length range of $(10-14 \pm 1 \mathrm{~mm}$.), showed regression after soft liner application during a period range $6-8$ weeks, but the lesion did not disappear only in 3 cases.

Treatment methods: In this study, four treatment methods were applied according to the pilot study depending on the length of the lesion.

Method No. 1: This method was applied to the clinical cases with lesion of $2-4 \pm 1 \mathrm{~mm}$. as follows:

1.Removing the prosthesis for 1-2 weeks.

2. Correcting the errors of complete dentures by trimming to make clear of the hyperplastic tissue without prejudice to its retention and stability of the dentures.

3. Instructing the patient for good oral hygiene.

4. Instructing the patient to wear the dentures at day only. The patient was examined each 2 weeks for 2 months.

5.Construction of new dentures.

Method No. 2: This method was applied to the clinical cases with the lesion size length $(5-9 \pm 1 \mathrm{~mm}$.) as follows:

1.Removing the prosthesis for 1-2 weeks.

2. Correcting the errors of complete dentures.

3. Instructing the patient for good oral hygiene.

4. The offending flange can be modified, or relieved at the site of the lesion followed by lining the denture with tissue condiioner material (OMF DENT). Change the material each 7 days for 8 weeks.

5. Construction of new dentures.

Method No. 3: This method was applied to the clinical cases with lesion size $(10-14 \pm 1 \mathrm{~mm}$.) as follows:

1. Removing the prosthesis for 1-2 weeks.

2. Correcting the errors of complete dentures

3. Instructing the patient for good oral hygiene.

4. The offending flange can be modified, or relieved at the site of the lesion followed by lining the denture with self curing COE-SOFT material. Change the material each 14 days for 8 weeks.

5.Construction of new dentures.

Method No. 4: This method was applied to the clinical cases with lesion size (length $15-19 \pm 1 \mathrm{~mm}$.) as follows:

1. Removing the prosthesis for 1-2 weeks.

2. Correcting the errors of complete dentures.

3. Instructing the patient for good oral hygiene.

4. Surgical removal of the granuloma (hyperplastic tissue). The flange can be corrected or relieved at the site of operation, the denture was lined with tissue conditioner. Change the material each 7 days for 8 weeks.

5. Construction of new dentures.

For each patient, two casts were prepared after each month of treatment to measure the size of the lesion (Figures 2, 3). Trimming the periphery of the old denture flange for all the cases was com-pared with the new denture flange length. Measurements were done using modified sliding caliper gauge.
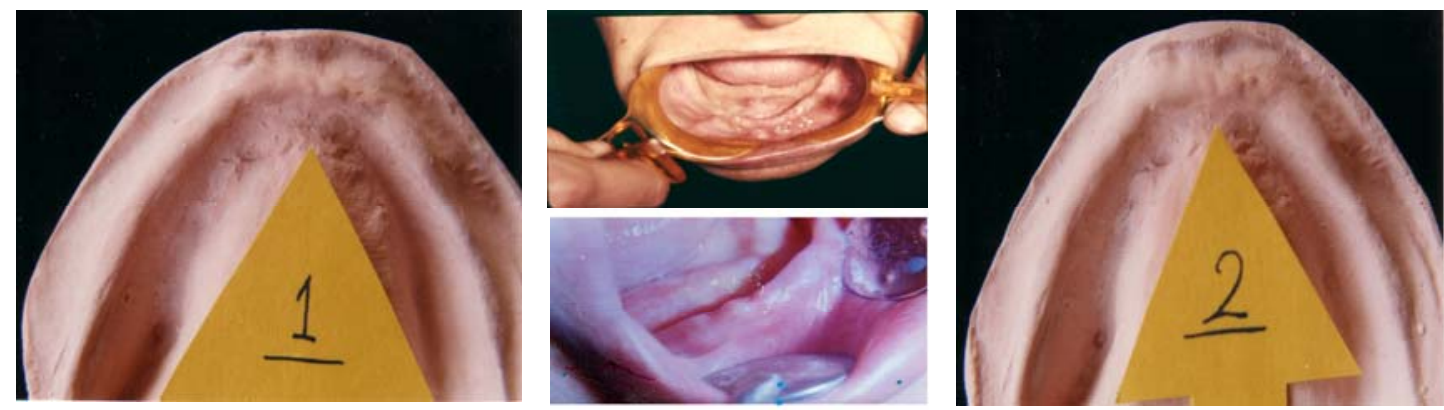

Figure (2): Denture Granuloma in the mandibular arch before and after treatment of clinical case. 

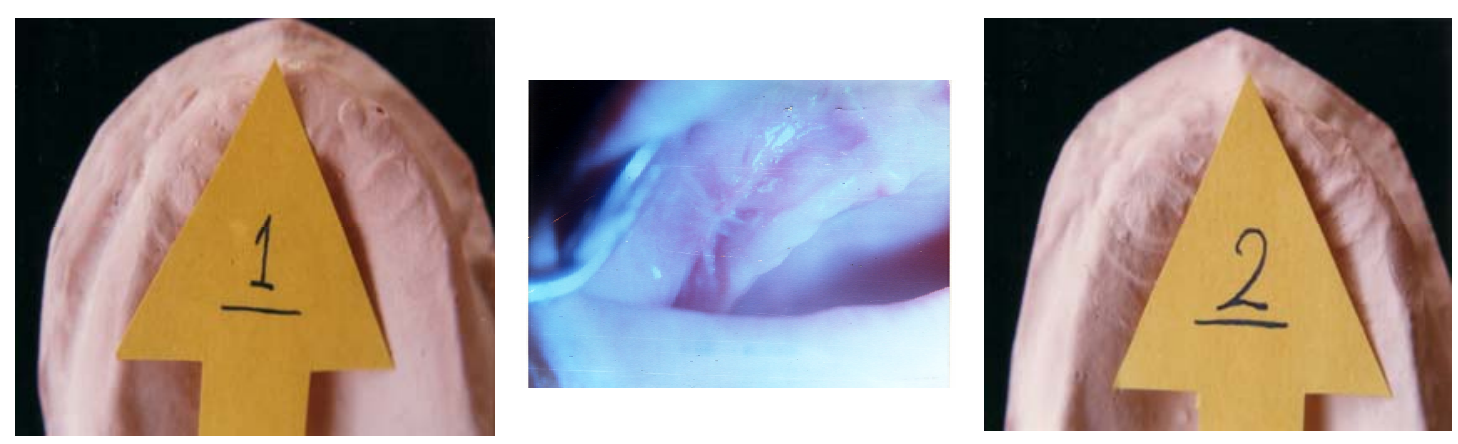

Figure (3): Denture Granuloma in the maxillary arch before and after treatment of clinical case.

\section{RESULTS AND DISCUSSION}

Complete questionnaires provided the data shown in Tables (1-6). This study showed high percentage $67.44 \%$ of older completely edentulous women with denture granuloma than men did at age range 41-70 years Tables ( 1 and 2). This is due to postmenopausal hormonal changes make the mucosal lining more susceptible to such a hype- rplastic reaction $^{(9)}$.

Women wear their dentures more frequently and for longer periods than men do for esthetic reasons ${ }^{(10)}$.

The results showed higher percentage of denture granuloma in the mandibular arch than maxillary arch $76.74 \%$. In labial vestibule of canine and premolar regions were $47.73 \% \mathrm{Ta}$ ble (3).

Table (1): Age and sex distribution of patients with denture granuloma.

\begin{tabular}{|c|c|c|c|c|c|c|}
\hline \multirow{2}{*}{ Age-Year } & \multicolumn{2}{|c|}{$\begin{array}{c}\text { Patient } \\
\text { Male And Female }\end{array}$} & \multicolumn{2}{|c|}{ Male } & \multicolumn{2}{|c|}{ Female } \\
\hline & Number & $\%$ & Number & $\%$ & Number & $\%$ \\
\hline $41-45$ & 12 & 6.98 & 7 & 12.5 & 5 & 4.31 \\
\hline $46-50$ & 15 & 8.72 & 5 & 8.92 & 10 & 8.62 \\
\hline $51-55$ & 21 & 12.21 & 9 & 16.07 & 12 & 10.34 \\
\hline $56-60$ & 34 & 19.77 & 10 & 17.85 & 24 & 20.68 \\
\hline $61-65$ & 39 & 22.67 & 13 & 23.21 & 26 & 22.41 \\
\hline $66-70$ & 51 & 29.65 & 12 & 21.42 & 39 & 33.62 \\
\hline 41-70 & 172 & 100 & 56 & 32.56 & 116 & 67.44 \\
\hline
\end{tabular}

Table (2): Numbers and percentage of patients with denture granuloma.

\begin{tabular}{ccccccccc}
\hline \multirow{2}{*}{ Time } & \multicolumn{4}{c}{ Number of patients wearing complete dentures } \\
\cline { 2 - 9 } (Year) & \multicolumn{4}{c}{ 24 Hour } & \multicolumn{5}{c}{ 16 Hour of Day } \\
\cline { 2 - 9 } & Male & \% & Female & \% & Male & \% & Female & \% \\
\hline $\mathbf{2 - 3}$ & 5 & 2.90 & 18 & 10.46 & 7 & 4.07 & 16 & 9.30 \\
$\mathbf{3 - 4}$ & 14 & 8.14 & 19 & 11.05 & 8 & 4.65 & 21 & 12.27 \\
$\mathbf{4 - 5}$ & 11 & 6.40 & 29 & 16.89 & 11 & 6.40 & 13 & 7.56 \\
\hline
\end{tabular}

Table (3): Location of the denture granuloma in the maxillary and mandibular arches.

\begin{tabular}{|c|c|c|c|c|c|c|c|c|c|c|}
\hline \multirow{3}{*}{\multicolumn{2}{|c|}{ Arch }} & \multicolumn{8}{|c|}{ Location of the denture granuloma } & \multirow{3}{*}{ Total } \\
\hline & & \multicolumn{2}{|c|}{ Crest of ridge } & \multicolumn{4}{|c|}{ Labial VestibuleLingual Vestibult } & \multicolumn{2}{|c|}{ Buccal Vestibule } & \\
\hline & & Incisal & Canine & Incisal & Canine & Incisal & Canine & Premolar & Molar & \\
\hline \multirow{2}{*}{ Max. } & No. & 2 & 1 & 9 & 9 & 0.0 & 0.0 & 11 & 8 & 40 \\
\hline & $\%$ & 5 & 2.5 & 22.5 & 22.5 & 0.0 & 0.0 & 27.5 & 20 & 23.26 \\
\hline \multirow{2}{*}{ Man. } & No. & 4 & 5 & 10 & 53 & 9 & 4 & 37 & 10 & 132 \\
\hline & $\%$ & 3.03 & 3.78 & 7.58 & 40.15 & 6.82 & 3.03 & 28.03 & 7.58 & 76.74 \\
\hline \multirow{2}{*}{ Total } & No. & 6 & 6 & 19 & 62 & 9 & 4 & 48 & 18 & 172 \\
\hline & $\%$ & 3.49 & 3.49 & 11.05 & 36.05 & 5.23 & 2.33 & 27.9 & 10.46 & 100 \\
\hline
\end{tabular}


Statistical analysis showed high significance between the position of denture granuloma of maxillary arch in relation to mandibular arch $\left(\mathrm{X}^{2}=\right.$ 18.503, d.f. $=7, P>0.01)$. Because the mean denture bearing area to be 22.96 $\mathrm{cm}^{2}$ in the edentulous maxillae and approximately $12.25 \mathrm{~cm}^{2}$ in the edentulous mandible, besides that with age, gender, and the denture bearing area (basal seat) becomes progressively smaller as residual ridges undergo resorption $^{(14)}$. This is also related to thin mucosal layer and prominence of bone in this area ${ }^{(6)}$.

Granuloma in the mandibular lingual vestibule showed less percentage than other regions (Figure 4). The lining mucosa of the floor of the mouth is sensitive to all kinds of irritation because it is poorly keratinized ${ }^{(15)}$.

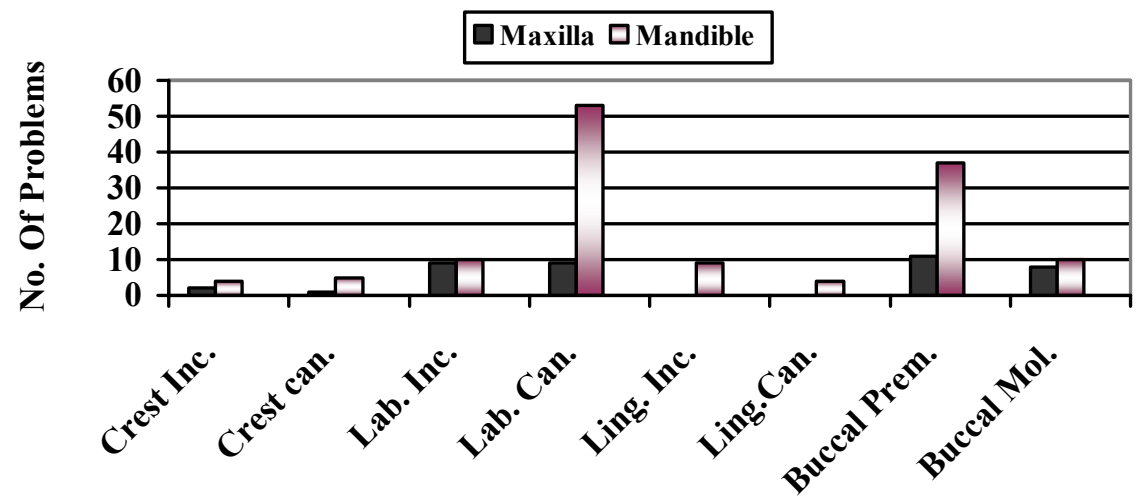

Figure (4): Distribution of the denture granuloma in the maxillary and mandibular Arches.

Denture problems associated with denture granuloma were calculated and analyzed in Tables (3-6), and (Figures 5-7). The results were showed a high incidence of denture problems in patients wearing the dentures day and night continuously (more than two problems $)^{(15)}$.

Table (4): Problems leading to denture granuloma.

\begin{tabular}{ccccccc}
\hline $\begin{array}{c}\text { Time of } \\
\text { wearing } \\
\text { denture }\end{array}$ & $\begin{array}{c}\text { Range } \\
\text { of size } \\
(\mathbf{m m})\end{array}$ & $\begin{array}{c}\text { Increase } \\
\text { flange } \\
\text { extension }\end{array}$ & $\begin{array}{c}\text { Poor retention } \\
\text { \& occlusal } \\
\text { errors }\end{array}$ & $\begin{array}{c}\text { Poor oral } \\
\text { hygiene }\end{array}$ & $\begin{array}{c}\text { Decrease } \\
\text { vertical } \\
\text { dimension }\end{array}$ & Total \\
\hline $\mathbf{2}-\mathbf{3}$ & $5-9 \pm 1$ & 11 & 5 & 10 & 13 & 39 \\
$\mathbf{3}-\mathbf{4}$ & $10-14 \pm 1$ & 31 & 17 & 18 & 33 & 99 \\
$\mathbf{4}-\mathbf{5}$ & $15-19 \pm 1$ & 33 & 33 & 25 & 40 & 131 \\
\hline $\mathbf{X 2}$ & $\mathbf{d . f .}$ & $3.245^{*}$ & $7.629 * *$ & 0.842 & $3.039^{*}$ & $4.832^{* *}$ \\
\hline${ }^{*} P \leq 0.05 ; * * P \geq 0.025 ;$ & d.f. $=$ degree of freedom. & & & \\
\end{tabular}

Table (5): Size of granuloma and denture problems of patients wearing denture 15-16 hours daily.

\begin{tabular}{|c|c|c|c|c|c|c|c|}
\hline \multicolumn{2}{|c|}{$\begin{array}{c}\text { Number of } \\
\text { Patient }\end{array}$} & \multirow{2}{*}{$\begin{array}{c}\text { Size } \\
(\mathbf{m m} .)\end{array}$} & \multirow{2}{*}{$\begin{array}{l}\text { Over Extension } \\
\text { of Flange }\end{array}$} & \multirow{2}{*}{$\begin{array}{l}\text { Poor retention } \\
\text { \& occlusal } \\
\text { errors }\end{array}$} & \multirow{2}{*}{$\begin{array}{l}\text { Poor oral } \\
\text { hygiene }\end{array}$} & \multirow{2}{*}{$\begin{array}{c}\text { Decrease } \\
\text { vertical } \\
\text { dimension }\end{array}$} & \multirow[t]{2}{*}{ Total } \\
\hline Male & Female & & & & & & \\
\hline 7 & 16 & $2-4 \pm 1$ & 5 & 5 & 5 & 8 & 23 \\
\hline 8 & 21 & $5-9 \pm 1$ & 11 & 7 & 5 & 15 & 38 \\
\hline 11 & 13 & $10-14 \pm 1$ & 19 & 13 & 7 & 26 & 65 \\
\hline \multicolumn{3}{|c|}{ Total } & 35 & 25 & 17 & 49 & 126 \\
\hline $\mathrm{X} 2$ & & d.f. $=2$ & 2.375* & 0.893 & 0.219 & 2.256* & $2.087 *$ \\
\hline
\end{tabular}


Table (6): Size of granuloma and denture problems of patients wearing denture continuously.

\begin{tabular}{|c|c|c|c|c|c|c|c|}
\hline \multicolumn{2}{|c|}{$\begin{array}{c}\text { Number of } \\
\text { Patient }\end{array}$} & \multirow{2}{*}{$\begin{array}{l}\text { Size } \\
(\mathbf{m m} .)\end{array}$} & \multirow{2}{*}{$\begin{array}{l}\text { Over Extension } \\
\text { of Flange }\end{array}$} & \multirow{2}{*}{$\begin{array}{c}\text { Poor retention } \\
\text { \& occlusal } \\
\text { errors }\end{array}$} & \multirow{2}{*}{$\begin{array}{l}\text { Poor oral } \\
\text { hygiene }\end{array}$} & \multirow{2}{*}{$\begin{array}{l}\text { Decrease } \\
\text { vertical } \\
\text { dimension }\end{array}$} & \multirow[t]{2}{*}{ Total } \\
\hline Male & Female & & & & & & \\
\hline 5 & 18 & $5-9 \pm 1$ & 11 & 5 & 10 & 8 & 39 \\
\hline 14 & 19 & $10-14 \pm 1$ & 31 & 17 & 18 & 15 & 99 \\
\hline 11 & 29 & $15-19 \pm 1$ & 33 & 33 & 25 & 26 & 131 \\
\hline \multicolumn{3}{|c|}{ Total } & 75 & 55 & 53 & 49 & 269 \\
\hline $\mathrm{X} 2$ & & d.f. $=2$ & $3.245 *$ & $7.629 * * *$ & 0.842 & 3.039* & $4.832 * *$ \\
\hline
\end{tabular}

Statistically the results were high significant of $\left(X^{2}=4.832\right.$, d.f. $=2$, $P>0.05)$. There was a high significant relation between the problems, time, and size of the lesion of denture granuloma ${ }^{(16-18)}$. This is because of the negative pressure on the tissue ${ }^{(19)}$.

Insufficient vertical dimension of occlusion showed a significant factor that leads to denture granuloma ${ }^{(11,20,}$ and 21)

But the fitness of the denture with occlusal errors play as an important factors in patient wearing dentures continuously $^{(22,23)}\left(\mathrm{X}^{2}=7.629\right.$, d.f. $=2$, $P<0.01)$. Improving good oral hygiene was inversely related with patient wearing denture continuously ${ }^{(22,24)}$.

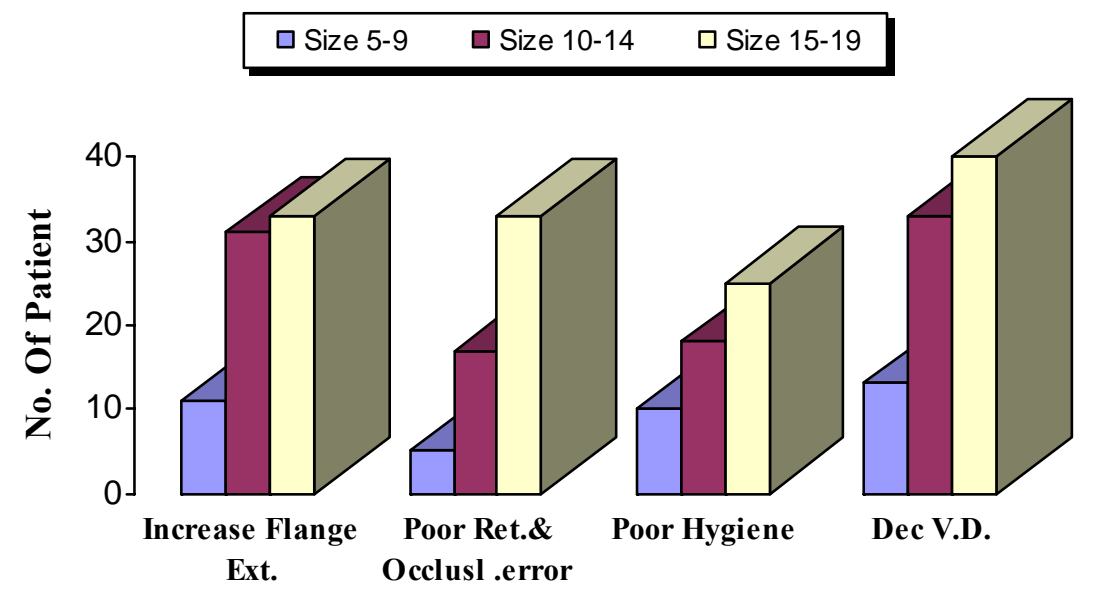

Figure (5): Errors in complete maxillary and mandibular dentures.

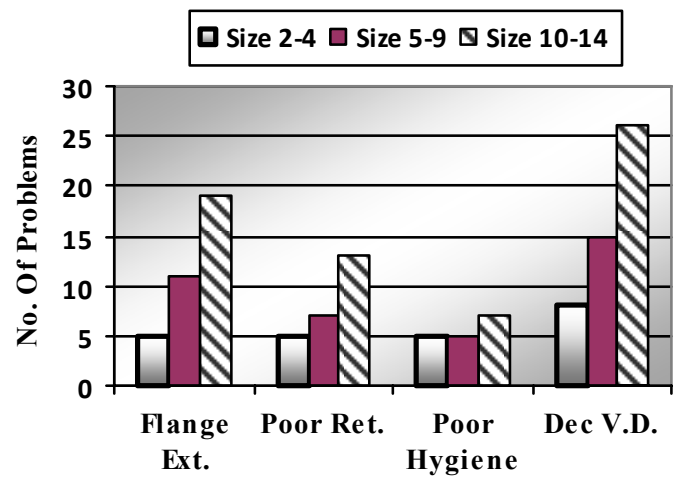

Figure (6): Size of gtranuloma and denture problems(15-16hours daily)



Figure (7): Size of gtranuloma and denture problems(24hours) 
Table (7) and (Figure 8): $66.27 \%$ of total treated patients showed complete disappearance of the lesion according to the treatment methods. A longer period is needed for the recovery of displaced mucosa in elderly people $^{(17)}$. Recovery period should be allowed before making impressions to allow decrease in the size of the lesion $^{(9,10,25,26)}$.

The results showed high significance of $X^{2}$ to $P>0.005$ regarding the applied treatment methods in relation to the size of granuloma (Figure 8). Using of soft lining materials clinically with granuloma of large size proved to give better results in relation to tissue conditioner, because soft lining materi-al remains soft and resilient for a peri-od of time to withstand the deforming load. Resilient base permits broader contact with the tender tissues and permits healing without further trauma ${ }^{(27)}$, and acts as stress breaker under occlusal forces. In addition, a flexible peripheral border reduces irritation slightly when over extended flanges yield without displacing the denture ${ }^{(14,}$ 28)

Table (7) also showed an increase in the reduction of the surface area of the denture flange toward the method IV. This is due to the reduction in vestibular depth, and scar formation after surgical operation ${ }^{(7)}$.

This will affect the retentive factor of complete denture because there is a relation between maximum coverage of surface area in relation to good retention $^{(14)}$.

Table (7): Treatment methods of Denture Granuloma.

\begin{tabular}{|c|c|c|c|c|c|c|c|}
\hline \multirow{3}{*}{$\begin{array}{c}\text { Number } \\
\text { of Pa- } \\
\text { tients }\end{array}$} & \multirow{3}{*}{$\begin{array}{l}\text { Size } \\
(\mathbf{m m} .)\end{array}$} & \multirow{3}{*}{$\begin{array}{l}\text { Treatment } \\
\text { methods }\end{array}$} & \multicolumn{4}{|c|}{ Results of Treatment } & \multirow{3}{*}{$\begin{array}{c}\text { Reduction } \\
\text { in Length } \\
\text { of Flange } \\
\text { (mm.) }\end{array}$} \\
\hline & & & \multicolumn{2}{|c|}{ Disappear } & \multicolumn{2}{|c|}{ Regression } & \\
\hline & & & No. & $\%$ & No. & $\%$ & \\
\hline 23 & $2-4 \pm 1$ & I & 23 & 100 & 0.0 & 0.0 & $1 \pm 0.5$ \\
\hline 52 & $5-9 \pm 1$ & II & 47 & 90.38 & 5 & 9.62 & $2.32 \pm 0.5$ \\
\hline 57 & $10-14 \pm 1$ & III & 31 & 54.39 & 26 & 45.61 & $3.64 \pm 0.5$ \\
\hline 40 & $15-19 \pm 1$ & IV & 13 & 32.5 & 27 & 67.5 & $8.24 \pm 0.5$ \\
\hline $\mathrm{X}^{2}=49.2$ & d.f & & & & & & \\
\hline
\end{tabular}

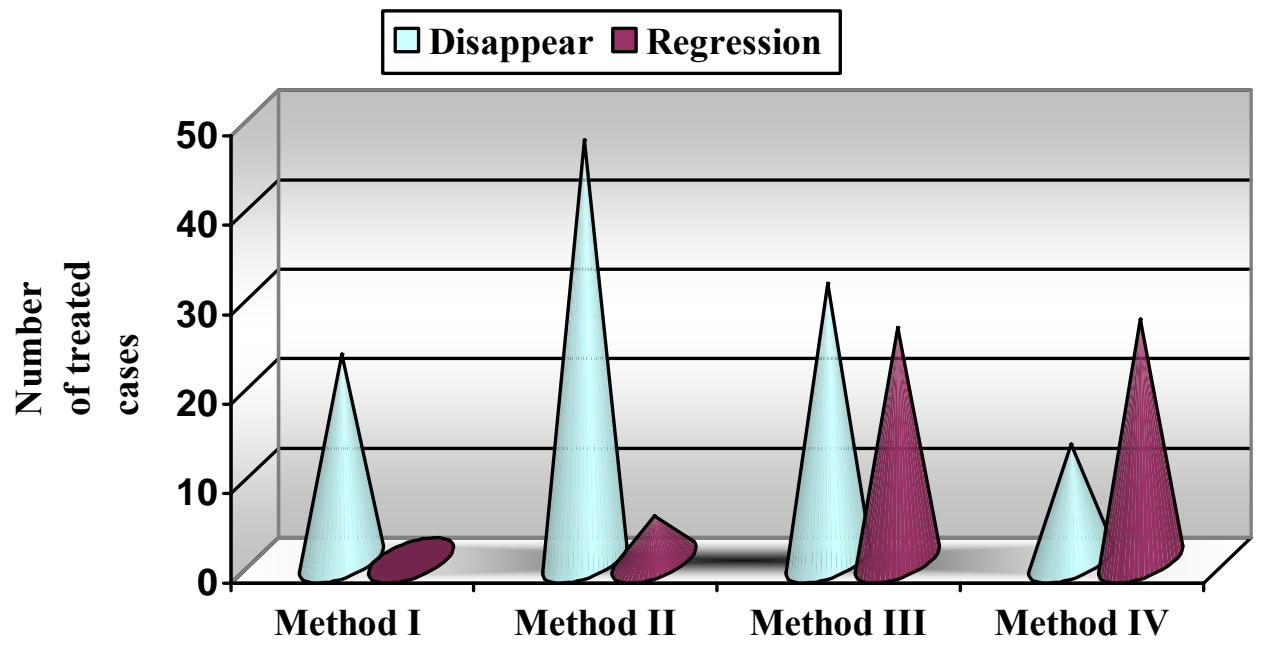

Figure (8): Treatment methods of denture granuloma. 


\section{CONCLUSIONS}

Carful examination of the mouth is very important. Rest period of 8 hours every day for supporting tissues is mandatory. Regular recall visits for patients wearing dentures is very important. Tissue recovery plays an important role in treatment of every size of denture granuloma. Avoid surgical treatment whenever possible, because it leads to reduction in surface area of denture base. Relining, rebasing, reseting teeth, and altering vertical height of complete dentures are recommendded every $3-5$ years if needed.

\section{REFERENCES}

1. Van Huysen G, Leonard L. Artificial dentures and the oral mucosa. $J$ Prosthet Dent. 1954; 4: 446-460.

2. Krolls SO, McGinnis JP. Case presentation Denture induced fibrous hyperplasia (epulis fissuratum). Miss Dent Assoc J. 1993; 49 (30): 18-19.

3. Academy of Prosthodontics. Glossary of prosthodontics terms. J prosthet Dent. 3005; 15: 95-101.

4. Kelly E. Tissue preparation for the complete denture patient. A simplified ap-proach. Dent Clinic of North Americ. 1970; 3: 441-445.

5. Cawson RA. Essentials of Dental Surgery and Pathology. Churchill Livingstone. British Library catalogue. $3^{\text {rd }}$ Ed. 1978; P: 202.

6. Tyldesley William R. A Colour Atlas of Oral Medicine. Wolfe medical publica-tions LTD. $1^{\text {st }}$ Ed. 1978; P: 77.

7. Miller EL. Types of inflammation caused by oral prosthesis. $J$ Prosthet Dent. 1973; 30(4): 380-384.

8. Ralph J, Stenhouse D. Denture induced hyperplasia of the oral soft tissues. Vestibular lesions, their characteristics and treatment. Brit Dent J.1972; 6870 .

9. Haddad I, Mneizel T. Treatment of dent-ure induced hyperplasia. Jordon Dent. 1994; 9(1): 35-39.

10. Khassawneh S. A survey of complete denture wearers problems. Jordon Dent. 1994; 9(1): 29-34.

11. Khmis MA, Metually ZM. Influence of tissue conditioning materials on the oral bacteriologic status of complete denture wearers. J Arab Dent Federa.1982; 1(1): 4-14.

12. Hand JS, Michael WJ. The prevalence of oral mucosal lesions in an elderly population. J Am Dent Assoc. 1986; 112: 73-78.

13. Neville BW. Oral and Maxillofacial Pathology. WB Saunders Company. $1^{\text {st }}$ Ed. 1978; Pp: 365-366.

14. Bataineh A, Al-Dwairi Z. A survey of localized lesions of oral tissues: A clinicopathological study. $J$ of Contemp Dent Prac. 2005; 6(3): 1-8.

15. Landa JS. Trouble shooting in 12 complete denture prosthesis Part I: oral mucosa and border extension. J Prosthet Dent. 1959; 9(6): 978-987.

16. Tautin FS. Should denture be worn continuously? J Prosthet Dent. 1978; 39(4): 372-374.

17. MacFntee M, Glick N, Stolar E. Age, gender, dentures and oral mucosal disorders. Oral Dis Mar. 1998; 4(1): 3236.

18. Dorey JL. Oral mucosal disorders in dentures wearers. $J$ Prosthet dent. 1985; 53(1): 210-213.

19. Lones PM. Complete dentures and associated soft tissues. J Prosthet Dent. 1976; 36(2): 136- 149.

20. Landa JS. Trouble shooting in complete denture prosthesis Part:II Lesions of the oral mucosa and their correction. J Prosthet Dent. 1960; 10(1): 42-46.

21. Bergman B , Carlsson G. Clinical long-term study of complete denture wearers. J Prosthet Dent. 1985; 53: 56-61.

22. Bernard CJ. Preprosthetic surgery for the edentulous patients. Dent Clinic North America. 1996; 40(1): 25.

23. Brunello DL, Mandikos MN. Construction faults, age, gender, and relative medical health: Factors associated with complains in complete denture patie- 
nts. J Prosthet Dent. 1998; 79(50): 545-554.

24. Karl KR. Basic procedure in oral surgery. Dent Clinic North America. 1994; 38: 208-209.

25. Judson HC, Stromberg RW. Preparation of the mouth for complete dentures. J Prosthet Dent. 1964; 14(4): 611-622.

26. William LD. The etiology of mucosal inflammation associated with dentures. J Prosthet Dent. 1967; 18(6): 515-527.

27. Edmund TA. Resilient tissue surface in complete dentures. $J$ Americ Dent Assoc. 1962; 64: 542-547.

28. Burns DR. Response of processed resilient denture liners to Candida Albicans. J Prosthet Dent. 1987; 57: 507512. 